\title{
Muscle Wasting and Sarcopenia in Heart Failure-The Current State of Science
}

\author{
Alessia Lena ${ }^{1,2,3,4, *}$, Markus S. Anker ${ }^{1,2,3,4}$ and Jochen Springer ${ }^{3,4}$ \\ 1 Division of Cardiology and Metabolism, Department of Cardiology, Charité-Campus Virchow \\ Klinikum (CVK), 13353 Berlin, Germany; markus.anker@charite.de \\ 2 Department of Cardiology, Charité-Campus Benjamin Franklin (CBF), 12203 Berlin, Germany \\ 3 Berlin Institute of Health Center for Regenerative Therapies (BCRT), 10178 Berlin, Germany; \\ jochen.springer@charite.de \\ 4 Deutsches Zentrum für Herz-Kreislauf-Forschung (DZHK) (German Centre for Cardiovascular Research), \\ Partner Site, 10785 Berlin, Germany \\ * Correspondence: alessia.lena@charite.de; Tel.: +49-30-450-553092; Fax: +49-30-450-553951
}

Received: 29 July 2020; Accepted: 28 August 2020; Published: 8 September 2020

check for updates

\begin{abstract}
Sarcopenia is primarily characterized by skeletal muscle disturbances such as loss of muscle mass, quality, strength, and physical performance. It is commonly seen in elderly patients with chronic diseases. The prevalence of sarcopenia in chronic heart failure (HF) patients amounts to up to $20 \%$ and may progress into cardiac cachexia. Muscle wasting is a strong predictor of frailty and reduced survival in HF patients. Despite many different techniques and clinical tests, there is still no broadly available gold standard for the diagnosis of sarcopenia. Resistance exercise and nutritional supplementation represent the currently most used strategies against wasting disorders. Ongoing research is investigating skeletal muscle mitochondrial dysfunction as a new possible target for pharmacological compounds. Novel agents such as synthetic ghrelin and selective androgen receptor modulators (SARMs) seem promising in counteracting muscle abnormalities but their effectiveness in HF patients has not been assessed yet. In the last decades, many advances have been accomplished but sarcopenia remains an underdiagnosed pathology and more efforts are needed to find an efficacious therapeutic plan. The purpose of this review is to illustrate the current knowledge in terms of pathogenesis, diagnosis, and treatment of sarcopenia in order to provide a better understanding of wasting disorders occurring in chronic heart failure.
\end{abstract}

Keywords: heart failure; sarcopenia; cardiac cachexia; treatment

\section{Introduction}

Sarcopenia is defined as a diminished muscle strength, rooted in a reduction of muscle quantity and quality, often associated with reduced physical performance, according to the new definition of the European Working Group on Sarcopenia in Older People [1]. Since muscle mass, strength, and function are strongly influenced by demographic and anthropometric features [2], worldwide uniformed threshold values have not been established yet. This limitation, in conjunction with other definitions adopted, leads inevitably to incongruities in the assessment of sarcopenia among different populations [3] (Table 1). Sarcopenia is commonly observed in older patients, with a prevalence between 10 and 40\%, depending on the definition used and the age range used in the studies [4]. The percentage of muscle mass loss progressively increases over the years, starting from the 5th decade with $1 \% / y e a r$ and reaching up to $50 \%$ by the 8 th-9th decade of life [5]. Interestingly, a recent meta-analysis of 41 studies and 34,955 participants showed that the prevalence of sarcopenia in nursing home individuals in the included studies were much higher (51\% (95\% CI: 37-66\%) in men and 31\% 
(95\% CI: $22-42 \%)$ in women) compared to community-dwelling individuals (11\% (95\% CI: 8-13\%) in men and 9\% (95\% CI: 7-11\%) in women), possibly due to lower activity levels in nursing homes [6].

Recent evidence suggests that a dysregulation of immunosenesence and low-grade progredient inflammatory response in elderly persons (inflammageing) $[7,8]$ may be involved in the development of sarcopenia $[9,10]$. Diet and physical activity have been associated with inflammatory activation in age-related sarcopenia [11]. In addition, epigenetic mechanisms may be involved in age-related muscular changes [12]—a study comparing blood DNA methylation in sarcopenic and non-sarcopenic old women ( $>65$ years) reported a lower methylation of differentially methylated cytosin-phosphate-guanine sites (dmCpGs) related to Kyoto Encyclopedia of Genes and Genomes (KEGG) signaling pathways associated with muscle function and energy metabolism in the sarcopenic group ( $p=0.004)$, suggesting that these processes might be epigenetically altered in ageing sarcopenia. Hypermethylated promoter regions of genes associated with metabolism in the sarcopenic group also indicate a possible suppression of cellular energy regulation in these subjects. Muscle wasting represents a major risk factor for decreased muscular resistance [13] and loss of independency in daily life activities (19.6\% vs. $13.8 \%$ of dependency, sarcopenia vs. non-sarcopenia, respectively, $p<0.001$ ) [14]. In a recent meta-analysis using 33 studies with more than 45,000 individuals, it was shown that sarcopenia was significantly associated with bone fractures. Sarcopenic individuals had a significant higher risk of falls (cross-sectional studies: Odds Ratio (OR): 1.60, 95\% CI: 1.37-1.86, $p<0.001$, I2 = 34\%; prospective studies: OR: $1.89,95 \%$ CI: $1.33-2.68, p<0.001$, I2 $=37 \%$ ) and fractures (cross-sectional studies: OR 1.84, 95\% CI 1.30-2.62, $p=0.001$, I2 $=91 \%$; prospective studies: OR 1.71, $95 \%$ CI 1.44-2.03, $p=0.011, \mathrm{I} 2=0 \%$ ) compared with non-sarcopenic individuals [15]. A study with 4452 disability-free adults aged $\geq 65$ years investigating disability in sarcopenia (mean follow-up 30 months) found that compared to non-sarcopenia, individuals with sarcopenia or low serum albumin alone had an increased risk of disability (Hazard ratio (HR): 2.74, 95\% CI: 1.58-4.77, and HR: 1.71, 95\% CI: 1.26-2.33, respectively), which was further increased in the groups that had both sarcopenia and low serum albumin (HR: 3.73, 95\% CI: 1.87-7.44) [16]. A prospective cohort of 534 individuals (73.5 \pm 6.2 years, $60.5 \%$ female) [17] showed a higher mortality $(16.2 \%$ vs. $4.6 \%, p<0.001)$ of individuals diagnosed with sarcopenia than of those who were not diagnosed after 3 years, if no association between baseline sarcopenia and physical disabilities or institutionalizations was highlighted [18]. A small study comparing 30 sarcopenic vs. 30 control individuals ( $77 \pm 6$ years, and $58 \%$ females) showed that sarcopenia may be associated with reduced diaphragmatic muscle thickness and respiratory functions.

The correct assessment of sarcopenia still represents a challenge for clinicians. Whether dual-energy X-ray absorptiometry (DXA) scan should represent the current reference standard for the skeletal muscle measurement is still a matter of debate $[19,20]$. High costs and scarce availability of this technique have led to the search for alternatives. The recent development of the D3-diluition method [21,22] with high reproducibility and minimized invasiveness has accomplished promising results in the estimation of skeletal muscle mass but its adoption in the clinical setting as a routine method remains to be implemented. A robust panel of biomarkers to detect the first signs of muscular degradation has not been established yet. Another frequently seen co-morbidity in these patients is cachexia, which is also in itself often accompanied by reduced hand grip strength and/or low walking speed [23], as well as worse performance in the short physical performance battery test [24]. However, a lack of uniform reference values for sarcopenic patients in these tests strongly demand a standardization in the clinical assessment of sarcopenia [25]. Recently, in a study based on 469,830 UK Biobank participants, associations of sarcopenia with adverse outcomes (all-cause mortality, incidence and mortality from cardiovascular disease (CVD), respiratory disease, and chronic obstructive pulmonary disease (COPD)) were strongest when sarcopenia was defined as slow gait speed plus low muscle mass, followed by severe sarcopenia, strongly suggesting that this combination of physical capability markers should still be considered in the diagnosis of sarcopenia [26]. The Asian Working Group for Sarcopenia studied the prevalence of 2061 older community residents ( $>60$ years of age) [27]. Comparing the AWGS2014 algorithm to the revised AWGS2019 algorithm [28] (slow gait speed cut-off at $<1 \mathrm{~m} / \mathrm{s}$ and prolonged 
five-time chair-stand time ( $\geq 12 \mathrm{~s})$ ), the authors identified 60 and 89 individuals with sarcopenia, respectively. Interestingly, the authors found a linear correlation between the severity of sarcopenia and carotid intima-media thickness (no sarcopenia: $0.94 \pm 0.31$, sarcopenia: $1.04 \pm 0.41$, and severe sarcopenia: $1.07 \pm 0.55 \mathrm{~mm}, p=0.003)$, which could be used as a new marker [29]. High levels of homocysteine (OR: 1.9, 95\% CI: 1.0-3.6) and high sensitive C-reactive protein (hsCRP) (OR: 3.9, 95\% CI: 2.2-6.9) were independently associated with sarcopenia in data of 1582 participants, with stronger correlations seen in women [30].

Sarcopenia can be a modifiable condition. A multimodal approach, based on physical activity [31,32] and dietary recommendation [33], seems currently to be the most effective strategy to counteract progressive age-dependent muscle impairments and improve quality of life as well as life expectancy. Recent evidence suggests that a protein intake above $1-1.5 \mathrm{~g} / \mathrm{kg} /$ day may positively influence the anabolic-catabolic imbalance in subjects suffering from sarcopenia [34]. An association of dietary habits (7-day food record) in 254 men with a mean age of 71 at baseline with the prevalence of sarcopenia 16 years later was described [35]. A healthy dietary pattern based on the dietary guidelines defined by the WHO tended to protect against the development of sarcopenia over 16 years. In particular, the authors found indications that increased adherence to a Mediterranean dietary pattern might be advantageous. The authors of a recent review suggest that elderly individuals with sarcopenia should eat at least three servings of fish a week to reach the minimal daily intake of 4-4.59 $\mathrm{g}$ of omega 3 , reaching the $50 \%$ of recommended daily allowance (RDA) in vitamin E and D. High biological value of proteins in $150 \mathrm{~g}$ of fish and its high available magnesium ( $20 \%$ of RDA in $150 \mathrm{~g}$ of fish) suggest fish as a "functional food" in sarcopenia [36]. It has been shown that the combination of malnutrition and sarcopenia showed a synergistically accumulated risk for death in a prospective analysis of 427 hospitalized old adults over 80 years [37]. A metabolic signature has been described in a cohort of 189 sarcopenic individuals in which levels of essential amino acids including lysine, methionine, phenylalanine, threonine, as well as branched-chain amino acids and choline were inversely correlated with sarcopenia. Furthermore, nicotine metabolites (cotinine and trans-3'-hydroxycotine) and vitamin B6 status were linked to one or more clinical and functional measures of sarcopenia [38].

Other studies are investigating the molecular mechanisms involved in mitochondrial function [39] that might be relevant for muscle homeostasis in older age and could represent a new target for pharmaceutical interventions. Recent findings in older mice attribute a certain importance to peroxisome proliferator-activated receptor gamma coactivator 1-alpha (PGC-1 $\alpha$ ), whose expression is enhanced by physical exercise, leading to increased oxidative phosphorylation (OXPHOS) protein levels in mitochondria beyond levels induced by exercise in wild type mice, while a muscle-specific PGC- $1 \alpha$ knockout resulted in blunting the exercise-controlled increase in OXPHOS proteins [40]. A recent publication shows that humans with sarcopenia, independently of their ethnicity, reproducibly exhibit a prominent transcriptional signature of mitochondrial bioenergetic dysfunction as evidenced by low PGC- $1 \alpha / E R R \alpha$ signaling and downregulation of mitochondrial proteostasis genes. These changes result in fewer mitochondria, reduction of respiratory complex expression and activity, as well as low nicotinamide adenine dinucleotide (NAD+) levels due to its disturbed biosynthesis [41].

The protein kinase mechanistic target of rapamycin (mTOR) is also a crucial modulator for cell growth and its loss in skeletal muscles has been recently investigated in knockout mouse models, suggesting that mTOR activity is essential for the regulation of peroxisome proliferator-activated receptor (PPAR) and PPAR-gamma coactivator 1-alpha (PPAR/PGC-1 $\alpha$ )-mediated OXPHOS capacity in vivo [42]. Furthermore, a mutant mTOR lacking the kinase activity induces robust suppression of postnatal muscle mammalian target of rapamycin complex 1 (mTORC1) signaling [42], demonstrating damaging effects of mTOR mutations in muscle metabolism. Surprisingly, mTORC1 is hyperactivated in sarcopenic muscle and a partial inhibition by novel compound (RAD001) resulted in an attenuation of sarcopenia shown by increased muscle mass and fiber type cross-sectional area, as well as downregulation of several genes associated with senescence. Hence, RAD001 may be considered a potential sarcopenia treatment [43]. 
Despite recent advances, the underlying mechanisms characterizing sarcopenia in ageing are still under investigation in preclinical as well as in clinical settings. Because of its negative impact on the quality of life it is necessary to increase the knowledge of this wasting process and to find preventive and therapeutic measures that may also be applied in patients with chronic diseases.

Therefore, the aim of this review is to increase clinical awareness of sarcopenia, with a particular focus on current pathogenetic knowledge and therapeutic possibilities that may counteract wasting disorders in chronic heart failure.

\section{Sarcopenia in $\mathrm{HF}$}

Heart failure (HF) is a systemic disease afflicting up to $2 \%$ of the population worldwide $[44,45]$. Although it represents a major burden in terms of expenditure of socio-economic resources and costs [46], the successful accomplishments in diagnostics [47] and treatment [48-50] achieved in the last decades have led to an improvement in outcomes [51] and to an increased life expectancy [52]. Consequently, the number of older HF patients with increasing clinical complexity is progressively growing [53]. As a result, a multimodal approach is needed, combining many different medical disciplines to treat non-cardiac co-morbidities such as wasting disorders [54] and to lead to an improvement of different secondary outcomes as well [55,56]. Muscle wasting is one of the main causes for exercise intolerance and ventilatory inefficiency in HF patients [57]. It promotes the aggravation of other clinical conditions and causes a deterioration of quality of life [58]. It is associated with a longer hospital stay [59], more frequent re-hospitalizations [60], and worsened prognosis [61]. In the Studies Investigating Co-morbidities Aggravating Heart Failure (SICA-HF) [62], which enrolled 200 chronic HF patients, the prevalence of sarcopenia in HF patients with reduced ejection fraction (HFrEF) was nearly $20 \%$ higher than in healthy adults of the same age $[62,63]$. Similar results have been observed in HF patients with a preserved ejection fraction [64,65]. Therefore, sarcopenia and chronic HF seem to be intertwined, complicating the progression and outcome of each other [66]. Sarcopenia can even be found in obese HF patients ("sarcopenic obesity" [67]) with a prevalence between $1.3 \%$ and $17.5 \%$ [68]. Even though these patients show higher amounts of body fat, they have lower muscle mass [69]. Many different mechanisms can influence the muscle metabolism in HF patients such as hyper-activation of the sympathetic system, systemic inflammation, and an alteration of neuro-hormonal release [70]. Elevated oxidative processes, increased activity of the ubiquitin-proteasome system, higher apoptotic activity, and reduced release of the skeletal muscle growth factors contribute to a generalized catabolic shift in the muscular tissue homeostasis [71]. As a result of these alterations, a systemic enhanced protein degradation causes muscle wasting. It is primarily characterized by atrophy of the fast-twitching type II myofibers but also the slow-twitching type I myofibers, decreased muscular capillary density, and fat infiltration [72].

HF patients present with various hormonal disturbances [73]—impaired expression of insulin growth factor 1 (IGF-1) [74], vitamin D deficiency [75], reduced levels of testosterone [76], and reduced levels of growth hormone (GH) [77] have been reported. A cross-sectional study with 3276 elderly participants, with sarcopenia defined by the Asian Working Group on Sarcopenia diagnostic criteria, showed that the appendicular skeletal muscle mass was positively associated with gender and Body Mass Index (BMI), as well as with GH, testosterone, IGF-1, mechanical growth factor (MGF), urea nitrogen, creatinine, and $\mathrm{Hb}$ levels, but negatively associated with HDL-C (all $p<0.05$ ). Using logistic multivariable regression analysis, the authors showed an independent association between IGF-1, MGF, BMI, and gender with appendicular skeletal muscle mass (all $p<0.05$ ) [78]. Since the IGF-1/GH axis contributes to the preservation of skeletal muscle mass [72], its modulation by supplementation of these hormones has been hypothesized to treat sarcopenia in older adults [79], but there is still no robust evidence of beneficial effects [80].

Vitamin D deficiency is common in old age [81], and there is evidence that this condition enhances the risk of falls and declined physical performance [82]. Additionally, low levels of vitamin D have been associated with risk of HF in elderly individuals [83]. Its supplementation in adults aged 60 years 
and older has reported positive results, increasing muscle strength and performance [82]. However, its replacement in chronic HF patients has only demonstrated improvements in the inflammatory profile but not in the exercise capacity nor in outcomes [84,85].

Low endogenous testosterone may represent an independent risk factor for HF [86]. Experimental administration of testosterone as a possible strategy to counteract exercise intolerance and dyspnoea in chronic HF has been investigated, describing positive results regarding reduction of symptoms [87] and increase of exercise capacity [88] in HF patients. However, the safety of testosterone supplementation and its potential negative effects on the cardiovascular system [89] (i.e., ischemic stroke, acute coronary syndrome, myocardial ischemia, congestive heart failure, death from coronary disease) have to be further examined [90].

Even though many HF patients experience a reduced exercise tolerance, resistance training has been demonstrated to be a positive stimulus on muscle mass, muscle quality, and physical performance in patients with HF [91]. The combination with aerobic exercise seems to exert anti-atrophic [92] as well as anti-inflammatory effects [93]. In general, physical activity is beneficial to prevent wasting [94] and to improve quality of life and prognosis in these patients $[95,96]$.

With regards to medical treatment of sarcopenia, supplementation of essential amino acids (8 g/day) have shown positive results regarding the physical performance, but did not increase absolute muscle mass in patients with stable chronic HF and severe loss of muscle mass [97]. Some standard HF medications have demonstrated potential benefits against muscle loss. Angiotensin II-converting enzyme inhibitors (ACE-Is), due to their anti-oxidative and anti-inflammatory effects, could have muscle protective effects [98]. In 1998, Vescovo et al. [99] reported in a small study in 16 HF patients that a 6-month treatment with enalapril $(n=8)$ or losartan $(n=8)$ improved exercise capacity. In 2003, a sub-analysis of the Studies of Left Ventricular Dysfunction (SOLVD) [100], including 1929 chronic HF patients, showed that patients taking enalapril had a 19\% lower risk of developing cachexia. Whether ACE-Is are beneficial in healthy older people remains unclear-a sub-analysis of the Berlin Aging Study II (BASE-II) study including 838 community-dwelling, elderly people found similar muscle mass, strength, and function in the patients with vs. without ACE-I [101], whereas a double-blind randomized controlled trial in 130 participants $\geq 65$ years with functional impairment showed better functional capacity after 20 weeks with ACE-I vs. placebo [102]. ACE-Is may also help in counteracting angiotensin II-dependent catabolic effects by modulating the GH/IGF-1 axis [103]. Blocking ACE and therefore the generation of Ang-II results in an upregulation of ACE2 expression and activity in skeletal muscle leading to increased levels of Ang1-7 and activation of its receptor (MasR), which contributes to an improved insulin sensitivity [104].

Beneficial effects of mineralocorticoid antagonists on skeletal muscle homeostasis have been postulated [105]. Despite some positive results on muscle quality in rats [106] and on exercise capacity in HF patients [107], Burton et al. [108] did not find an association between spironolactone and better physical function in a randomized placebo-controlled trial including 120 participants aged $>64$ years without HF.

Some studies suggest that beta-blockers may slow down wasting processes associated with increased sympathetic activation-in an analysis from the COPERNICUS trial [109], a double-blind, placebo-controlled randomized trial in 2289 patients with HF, carvedilol in comparison to placebo exhibited a 33\% lower risk of weight loss $>6 \%(95 \%$ CI: $14-48 \%, p=0.002)$ during 24 months of follow-up. The retrospective analysis of the COPERNICUS data confirmed the results of the prospective phase II ACT-ONE trial [110], a randomized, double-blind, placebo-controlled phase II study, including 87 colorectal and non-small cell lung cancer patients with cachexia, showing that espindolol (also termed ACM-001) was associated with weight gain of $2.83 \mathrm{~kg}$ (95\% CI: 1.00, 3.68) compared with a weight loss of $0.99 \mathrm{~kg}(95 \% \mathrm{CI}:-3.97,1.52)$ in the placebo group, increased lean body mass $(1.76 \mathrm{~kg}(95 \%$ CI: $1.43,3.18)$ compared with a gain of $0.57 \mathrm{~kg}(95 \% \mathrm{CI}:-0.01,1.71)$ in the placebo group $(p=0.012)$, and improved hand grip strength (high dose $-1.15 \pm 0.7 \mathrm{~kg}$, placebo $-3.51 \pm 0.8 \mathrm{~kg}$ change per 4 weeks; $p=0.0134)$. This effect was even more pronounced in a highly aggressive cancer cachexia rat model 
(Yoshida AH-130 hepatoma), in which treatment of espindolol at $3 \mathrm{mg} / \mathrm{kg} /$ day resulted in a prevention of the progressive loss of fat mass ( $-6 \pm 2 \mathrm{~g}$ vs. $-12 \pm 1 \mathrm{~g} ; p<0.001)$; lean mass $(+1 \pm 10 \mathrm{~g}$ vs. $-37 \pm 2 \mathrm{~g}$; $p<0.001)$ and body weight $(+1 \pm 13 \mathrm{~g}$ vs. $-60 \pm 2 \mathrm{~g} ; p<0.001)$ were stable. Most importantly, survival was significantly improved (HR: $0.29,95 \%$ CI: $0.16-0.51, p<0.001$ ). Mechanistically, espindolol reduces catabolic signaling (reduced myostatin, ubiquitin proteasome system (UPS) activity, autophagy), while increasing anabolic signaling (Protein kinase B, Akt/mTOR) [111]. Previously, the effects of espindolol on muscle mass in 19-month-old rats have been investigated, where $3 \mathrm{mg} / \mathrm{kg} /$ day espindolol treatment over a period of 4 weeks increased body weight $(+8.0 \pm 6.1 \mathrm{~g}, p<0.05)$, particularly lean mass $(+43.4 \pm 3.5 \mathrm{~g}, p<0.001)$, and reduced fat mass $(-38.6 \pm 3.4 \mathrm{~g}, p<0.001)$, while placebo rats progressively lost body weight $(-15.5 \pm 7.2 \mathrm{~g})$, lean mass $(-1.5 \pm 4.2 \mathrm{~g})$, and fat mass $(-15.6 \pm 2.7 \mathrm{~g})$, thereby reversing the effects of sarcopenia [112].

Currently, some compounds for wasting disorders in chronic HF are being tested in preclinical and clinical settings [113] - acylated ghrelin has a potential anti-catabolic effect, as demonstrated by an experimental study conducted in a chronic HF rat model [114], possibly by regulation of the UPS rate-limiting E-3 ubiquitin ligases, muscle RING-finger protein-1 (MuRF-1) and Muscle Atrophy F-box (MAFbx)/atrogin-1 [115]. Moreover, its intravenous administration in a small cohort of HF patients underlined an amelioration of exercise capacity and muscle strength [116]. Anamorelin, a non-peptide ghrelin analogue, was recently tested in healthy young men [117], exhibiting gain in appetite, food intake, and weight. In non-small cell lung cancer patients [118], the same compound produced additional improvement in the lean body mass and in cachexia symptoms. Recently, a chronic HF mouse study showed diaphragm fiber atrophy, an 20\% impaired contractile function, and reduced mitochondrial enzyme activities. Post left anterior descending artery-myocardial infarction (LAD-MI) treatment with the MuRF-1 inhibitor compound ID\#704946 partially prevented the chronic HF effects on the diaphragm [119].

The negative regulator of muscle mass myostatin (also known as Growth/differentiation factor 8 (GDF-8)) binds primarily to the activin II B receptor (ActRIIB) and is upregulated under catabolic conditions such as sarcopenia and cachexia. The knockout of myostatine gene led to a significantly increased muscle mass in mice [120]. However, the relationship between muscle mass and strength in these mice was not linear. There are spontaneous, natural gene deletions in animals such as Belgian Blue cattle; whippets; and, in a rare case, humans [121]. Human myocardium expressed increased levels of myostatin in end-stage heart failure compared the control group. The related signaling pathways in the myocardium were seen to have a gender effect [122]. Myostatin expressed and secreted by the myocardium is thought to be causal for skeletal muscle wasting in a transaortic constriction chronic HF mouse model [123]. Binding of activin A to ActRIIB in skeletal muscle was shown to induce muscle atrophy that was dependent on a p38beta Mitogen-Activated Protein Kinase (MAPK)-activated signaling pathway and resulted in the upregulation of ubiquitin ligases MAFbx and UBR2 (E3alpha-II), as well as increases in LC3-II, a marker of autophagosome formation [124]. Plasma activin A levels have been reported to be an independent predictor of survival in cancer patients [125]. Interestingly, doxorubicin-induced cachexia was attenuated by ActRIIB ligand blocking. Pre-treatment with soluble ACVR2B-Fc had only a minor impact on the cardiac muscle while it showed strong effects in skeletal muscle at the transcriptome level [126]. These data should make myostatin blocking an interesting strategy to counteract muscle loss in various conditions and diseases, however, while neutralizing antibodies such as MYO-029, AMG 74, LY2495655, or soluble receptor decoys such as ACE-11 and ACE-031 have significant beneficial effects on muscle mass and strength, they also exhibit several side effects including urticaria, aseptic meningitis, diarrhea, confusion, fatigue, and unintentional muscle contractions [79].

Different selective androgen receptor modulators (SARMs) [127] are currently being explored due to their potential anabolic activity but without side effects of androgens. Enobosarm showed some promising results in a double-blind, placebo-controlled phase II trial, enrolling cancer patients with at least $2 \%$ weight loss in the 6 months before recruitment. A significant increase in total lean body 
mass over 4 months was observed in patients treated with $1 \mathrm{mg}$ enobosarm once daily (median $1.5 \mathrm{~kg}$ (range 2.1-12.6 kg), $p=0.0012$ )) and $3 \mathrm{mg}$ enobosarm (median $1.0 \mathrm{~kg}$ (range $-4.8-11.5 \mathrm{~kg}$ ), $p=0.046$ ), while placebo resulted in no change (median $0.02 \mathrm{~kg}$ (range $-5.8-6.7 \mathrm{~kg}$ ), $p=0.88$ ) [128]. Nonetheless, there was no improvement in muscle strength nor physical performance. GSK2881078 [129], another SARM compound, determined dose-dependent gain in lean mass in healthy subjects, but a major response was observed in postmenopausal women while MK-4541 [130], an androgen receptor agonist with $5 \alpha$-reductase inhibitor function, exhibited anabolic effects and improvement of muscle function in castrated male mice. Despite the promising results, data from large-scale studies confirming the potential muscle-protective effects of these compounds in HF patients are not available yet.

Some of the mechanisms involved in muscular wasting such as mitochondrial dysfunction [131], overactivation of the ubiquitin-proteasome system [132], and abnormal cellular autophagy [66] are still under investigation and might be possible targets for future therapeutic options.

\section{Sarcopenia in Cardiac Cachexia}

A sarcopenic phenotype in patients may precede and present with cachexia in patients with advanced stages of HF [133], a condition associated with an extremely reduced survival [134]. Cachexia has been diagnosed in $19 \%$ of male patients with stable chronic HF, while $7 \%$ had both sarcopenia and cachexia [62]. Another study confirms that the prevalence of cachexia in chronic HF ranges from $10 \%$ [135] to $16 \%$ [136]. Cachexia seems to result in a progressive systemic tissue depletion, which involves the skeletal muscle and the fat tissue [137]. Clinically, it is defined by an unintentional weight loss of $\geq 5 \%$ in the last 12 months and three of the following five components: abnormalities in blood tests (increased inflammatory biomarkers, hemoglobin $<12 \mathrm{~g} / \mathrm{dL}$, and serum albumin $<3.2 \mathrm{~g} / \mathrm{dL}$ ), reduced muscular strength, anorexia, low fat-free mass index, and signs of fatigue [134]. It also occurs, under the common denominator of chronic inflammation $[138,139]$, in other various chronic diseases, e.g., in chronic obstructive pulmonary disease (COPD) [140], chronic kidney disease (CKD) [141,142], and cancer [143].

Contributing elements to the deleterious changes in body composition in patients with cardiac cachexia are anorexia, malnutrition, intestinal congestion [144], and an inflammatory cytokine storm, which have also been described as common complications in severe HF $[145,146]$. High serum levels of adiponectin [147], a protein involved in the cellular energy control of several tissues, have been found in HF patients with cachexia, unrelated to their body mass index [148]. This alteration describes its potential role as a biomarker of body fat changes, tissue wasting [149], as well as a predictor of mortality $[150,151]$ in these patients. Furthermore, an association between adiponectin resistance and peripheral muscle abnormalities was found in non-cachectic HF patients over 61 years [152].

Cardiac cachexia is also associated with myocardial atrophy in rodent models. One of the key regulators seems to be muscle-specific ring finger 1 (MuRF1) [153], an E3 ubiquitin ligase present in skeletal as well in cardiac muscle-experimental small molecule inhibition of apoptotic and ubiquitin-proteasome-dependent proteolysis showed promising results in reducing muscle atrophy and contractile dysfunction in rodents with cardiac cachexia [119].

The current literature does not provide evidence of available or experimental pharmacological agents able to prevent or delay the progression of cardiac cachexia. Some promising results on mitigating side effects of tumors on the heart and on the prognosis through HF medications derive from an experimental experience in rats with cancer cachexia [154]. 
Table 1. Comparison table of major diagnostic criteria and most frequently adopted cut-off points for sarcopenia.

\begin{tabular}{|c|c|c|c|c|c|c|c|}
\hline \multicolumn{2}{|c|}{ EWGSOP 2010} & \multicolumn{2}{|c|}{ EWGSOP2 2018} & \multicolumn{2}{|c|}{ AWGS 2019} & \multicolumn{2}{|c|}{ SDOC 2018} \\
\hline \multicolumn{2}{|c|}{ Creuz-Jentoft et al. (2010) [155] } & \multicolumn{2}{|c|}{ Creuz-Jentoft et al. (2019) [1] } & \multicolumn{2}{|c|}{ Chen et al. (2020) [28] } & \multicolumn{2}{|c|}{ Bhasin et al. (2020) [156] } \\
\hline \multicolumn{2}{|c|}{$\begin{array}{l}\text { "Progressive and generalized } \\
\text { loss of skeletal muscle mass } \\
\text { associated with low muscle } \\
\text { strength or low physical } \\
\text { performance." }\end{array}$} & \multicolumn{2}{|c|}{$\begin{array}{l}\text { "Sarcopenia is identified by } \\
\text { low muscle strength and } \\
\text { confirmed by additional low } \\
\text { muscle quantity. Low physical } \\
\text { performance describes a } \\
\text { severe status." }\end{array}$} & \multicolumn{2}{|c|}{$\begin{array}{l}\text { "Age-related loss of muscle } \\
\text { mass, associated with low } \\
\text { muscle strength and/or low } \\
\text { physical performance." }\end{array}$} & \multicolumn{2}{|c|}{$\begin{array}{l}\text { "Low muscle strength defined } \\
\text { by low grip strength and low } \\
\text { physical performance defined } \\
\text { by low usual gait speed } \\
\text { should be included in the } \\
\text { definition of sarcopenia." }\end{array}$} \\
\hline \multicolumn{2}{|c|}{ Low muscle mass } & \multicolumn{2}{|c|}{ Low muscle strength } & \multicolumn{2}{|c|}{ Loss of muscle mass } & \multicolumn{2}{|c|}{ Low muscle strength } \\
\hline DXA & $\begin{array}{l}\text { ASM } / \text { height }^{2}< \\
7.26 \mathrm{~kg} / \mathrm{m}^{2} \text { in } \\
\text { men } \\
\text { ASM } / \text { height }^{2}< \\
5.5 \mathrm{~kg} / \mathrm{m}^{2} \text { in } \\
\text { women }\end{array}$ & Handgrip & $\begin{array}{l}<27 \mathrm{~kg} \text { in men } \\
<16 \mathrm{~kg} \text { in } \\
\text { women }\end{array}$ & \multicolumn{2}{|r|}{$\begin{array}{l}\mathrm{SM} / \text { height }^{2}<7.0 \\
\mathrm{~kg} / \mathrm{m}^{2} \text { in men } \\
\mathrm{SM} / \mathrm{height}^{2}< \\
5.4 \mathrm{~kg} / \mathrm{m}^{2} \text { in } \\
\text { women }\end{array}$} & \multirow{2}{*}{\multicolumn{2}{|c|}{ Handgrip }} \\
\hline BIA & $\begin{array}{l}\mathrm{SM} / \mathrm{height}^{2}< \\
8.87 \mathrm{~kg} / \mathrm{m}^{2} \text { in } \\
\text { men } \\
\mathrm{SM} / \mathrm{height}^{2}< \\
6.42 \mathrm{~kg} / \mathrm{m}^{2} \text { in } \\
\text { women }\end{array}$ & $\begin{array}{c}\text { Chair } \\
\text { stand test }\end{array}$ & $>15 \mathrm{~s}$ for 5 rises & BIA & $\begin{array}{l}\mathrm{SM} / / \mathrm{height}^{2}< \\
7.0 \mathrm{~kg} / \mathrm{m}^{2} \text { in } \\
\text { men } \\
\mathrm{SM} / \mathrm{height}^{2}< \\
5.4 \mathrm{~kg} / \mathrm{m}^{2} \text { in } \\
\text { women }\end{array}$ & & \\
\hline Low $\mathrm{m}$ & cle strength & Low mus & $\begin{array}{l}\text { le quantity or } \\
\text { uality }\end{array}$ & Low $\mathrm{m}$ & cle strength & Low phys & al performance \\
\hline \multirow{3}{*}{ Handgrip } & \multirow{3}{*}{$\begin{array}{c}<30 \mathrm{~kg} \text { in men } \\
<20 \mathrm{~kg} \text { in } \\
\text { women }\end{array}$} & \multirow{2}{*}{ DXA, BIA } & $\begin{aligned} & \mathrm{ASM}<20 \mathrm{~kg} \text { in } \\
& \text { men } \\
& \mathrm{ASM}<15 \mathrm{~kg} \text { in } \\
& \text { women }\end{aligned}$ & \multirow{3}{*}{ Handgrip } & \multirow{3}{*}{$\begin{array}{c}<28 \mathrm{~kg} \text { in men } \\
<18 \mathrm{~kg} \text { in } \\
\text { women }\end{array}$} & \multirow{3}{*}{ Gait speed } & \multirow{3}{*}{$\begin{array}{l}\text { Cut points } \\
\text { dependent on } \\
\text { age, sex, } \\
\text { race/ethnicity, } \\
\text { and disease }\end{array}$} \\
\hline & & & $\begin{array}{l}\text { ASM } / \text { height }^{2}< \\
7 \mathrm{~kg} / \mathrm{m}^{2} \text { in men } \\
\mathrm{ASM} / \text { height }^{2}< \\
5.5 \mathrm{~kg} / \mathrm{m}^{2} \text { in } \\
\text { women }\end{array}$ & & & & \\
\hline & & MRI, CT & $\begin{array}{l}\text { Fat infiltration } \\
\text { in skeletal } \\
\text { muscle }\end{array}$ & & & & \\
\hline \multicolumn{2}{|c|}{ Low physical performance } & \multicolumn{2}{|c|}{ Low physical performance } & \multicolumn{2}{|c|}{ Low physical performance } & & \\
\hline SPPB & $\leq 8$ point score & Gait speed & $\leq 0.8 \mathrm{~m} / \mathrm{s}$ & $\begin{array}{c}\text { 6-m walk } \\
\text { test }\end{array}$ & $<1.0 \mathrm{~m} / \mathrm{s}$ & & \\
\hline $\begin{array}{l}\text { 6-m gait } \\
\text { speed }\end{array}$ & $<1.0 \mathrm{~m} / \mathrm{s}$ & TUG & $\geq 20 \mathrm{~s}$ & SPPB & $\leq 9$ point score & & \\
\hline \multirow[b]{2}{*}{$\begin{array}{l}\text { 4-m gait } \\
\text { speed }\end{array}$} & \multirow[b]{2}{*}{$<0.8 \mathrm{~m} / \mathrm{s}$} & SPPB & $\leq 8$ point score & \multirow{2}{*}{$\begin{array}{l}\text { Five-time } \\
\text { chair stand } \\
\text { test }\end{array}$} & \multirow[b]{2}{*}{$\geq 12 \mathrm{~s}$} & & \\
\hline & & $\begin{array}{c}400 \mathrm{~m} \\
\text { walk test }\end{array}$ & $\begin{array}{l}\text { Non-completion } \\
\text { or } \geq 6 \text { min for } \\
\text { completion }\end{array}$ & & & & \\
\hline $\begin{array}{l}\text { ASM, a1 } \\
\text { BIA, bio } \\
\text { Europe } \\
\text { Definiti } \\
\text { TUG, ti }\end{array}$ & $\begin{array}{l}\text { endicular skeleta } \\
\text { ectrical impedanc } \\
\text { Working Group } \\
\text { and Outcomes } \\
\text { ed-up-and-go-tes }\end{array}$ & $\begin{array}{l}\text { nuscle mass } \\
\text { analysis; C } \\
\text { n Sarcopen } \\
\text { onsortium; }\end{array}$ & $\begin{array}{l}\text { SM; total skeletal } \\
\text { computed tomog } \\
\text { a in Older People } \\
\text { M, total skeletal }\end{array}$ & $\begin{array}{l}\text { apscle mass; } \\
\text { aphy; DXA, } \\
\text { MRI, magn } \\
\text { huscle mass }\end{array}$ & $\begin{array}{l}\text { WGS, Asian Work } \\
\text { dal-energy X-ray a } \\
\text { tic resonance imc } \\
\text { SPPB, short phys }\end{array}$ & $\begin{array}{l}\text { ng Group fo } \\
\text { sorptiometr } \\
\text { ging; SDOC, } \\
\text { cal performa }\end{array}$ & $\begin{array}{l}\text { Sarcopenia; } \\
\text {; EWGSOP, } \\
\text { Sarcopenia } \\
\text { ce battery; }\end{array}$ \\
\hline
\end{tabular}

In conclusion, more efforts are needed to establish a worldwide, standardized definition and assessment of ageing as well as disease-related sarcopenia. More attention has to be paid to the early recognition and staging of wasting processes in HF. Large-scale trials in HF patients are needed to establish the efficacy and safety profile of new agents.

Author Contributions: All the authors contributed to the writing. All authors have read and agreed to the published version of the manuscript.

Funding: This research received no external funding. 
Conflicts of Interest: M.S.A. has received personal fees from Servier and research support from the German Center for Cardiovascular Research and by the BMBF (German Ministry of Education and Research). All other authors report no conflict of interest.

\section{References}

1. Cruz-Jentoft, A.J.; Bahat, G.; Bauer, J.; Boirie, Y.; Bruyère, O.; Cederholm, T.; Cooper, C.; Landi, F.; Rolland, Y.; Sayer, A.A.; et al. Sarcopenia: Revised European consensus on definition and diagnosis. Age Ageing 2019, 48, 601. [CrossRef] [PubMed]

2. Suetta, C.; Haddock, B.; Alcazar, J.; Noerst, T.; Hansen, O.M.; Ludivg, H.; Kamper, R.S.; Schnohr, P.; Prescott, E.; Frandsen, U.; et al. The Copenhagen Sarcopenia Study: Lean mass, strength, power, and physical function in a Danish cohort aged 20-93 years. J. Cachexia Sarcopenia Muscle 2019, 10, 1316-1329. [CrossRef] [PubMed]

3. Bauer, J.; Morley, J.E.; Schols, A.M.W.G.; Ferrucci, L.; Cruz-Jentoft, A.J.; Jatoi, A.; Kalantar-Zadeh, K.; Landi, M.; Laviano, A.; Mancuso, M.; et al. Sarcopenia: A Time for Action. An SCWD Position Paper. J. Cachexia Sarcopenia Muscle 2019, 10, 956-961. [CrossRef] [PubMed]

4. Mayhew, A.J.; Amog, K.; Phillips, S.; Parise, G.; McNicholas, P.D.; de Souza, R.J.; Thabane, L.; Raina, P. The prevalence of sarcopenia in community-dwelling older adults, an exploration of differences between studies and within definitions: A systematic review and meta-analyses. Age Ageing 2019, 48, 48-56. [CrossRef] [PubMed]

5. Wilkinson, D.J.; Piasecki, M.; Atherton, P.J. The age-related loss of skeletal muscle mass and function: Measurement and physiology of muscle fibre atrophy and muscle fibre loss in humans. Ageing Res. Rev. 2018, 47, 123-132. [CrossRef]

6. Papadopoulou, S.K.; Tsintavis, P.; Potsaki, P.; Papandreou, D. Differences in the Prevalence of Sarcopenia in Community-Dwelling, Nursing Home and Hospitalized Individuals. A Systematic Review and Meta-Analysis. J. Nutr. Health Aging 2020, 24, 83-90. [CrossRef]

7. Ferrucci, L.; Fabbri, E. Inflammageing: Chronic inflammation in ageing, cardiovascular disease, and frailty. Nat. Rev. Cardiol. 2018, 15, 505-522. [CrossRef]

8. Li, C.W.; Yu, K.; Shyh-Chang, N.; Li, G.X.; Jiang, L.J.; Yu, S.L.; Xu, L.Y.; Liu, R.J.; Guo, Z.J.; Xie, H.Y.; et al. Circulating factors associated with sarcopenia during ageing and after intensive lifestyle intervention. J. Cachexia Sarcopenia Muscle 2019, 10, 586-600. [CrossRef]

9. Cao Dinh, H.; Njemini, R.; Okwudiri Onyema, O.; Beyer, I.; Liberman, K.; De Dobbeleer, L.; Renmans, W.; Vander Meeren, S.; Jochmans, K.; Delaere, A.; et al. Strength Endurance Training but Not Intensive Strength Training Reduces Senescence-Prone T Cells in Peripheral Blood in Community-Dwelling Elderly Women. J. Gerontol. A Biol. Sci. Med. Sci. 2019, 74, 1870-1878. [CrossRef]

10. Wilson, D.; Jackson, T.; Sapey, E.; Lord, J.M. Frailty and sarcopenia: The potential role of an aged immune system. Ageing Res. Rev. 2017, 36, 1-10. [CrossRef]

11. Abete, I.; Konieczna, J.; Zulet, M.A.; Galmés-Panades, A.M.; Ibero-Baraibar, I.; Babio, N.; Estruch, R.; Vidal, J.; Toledo, E.; PREDIMED-PLUS Investigators; et al. Association of lifestyle factors and inflammation with sarcopenic obesity: Data from the PREDIMED-Plus trial. J. Cachexia Sarcopenia Muscle 2019, 10, 974-984. [CrossRef] [PubMed]

12. He, L.; Khanal, P.; Morse, C.I.; Williams, A.; Thomis, M. Differentially methylated gene patterns between age-matched sarcopenic and non-sarcopenic women. J. Cachexia Sarcopenia Muscle 2019, 10, 1295-1306. [CrossRef] [PubMed]

13. Moore, D.R.; Kelly, R.P.; Devries, M.C.; Churchward-Venne, T.A.; Phillips, S.M.; Parise, G.; Johnston, A.P. Low-load resistance exercise during inactivity is associated with greater fibre area and satellite cell expression in older skeletal muscle. J. Cachexia Sarcopenia Muscle 2018, 9, 747-754. [CrossRef] [PubMed]

14. Perez-Sousa, M.A.; Venegas-Sanabria, L.C.; Chavarro-Carvajal, D.A.; Cano-Gutierrez, C.A.; Izquierdo, M.; Correa-Bautista, J.E.; Ramírez-Vélez, R. Gait speed as a mediator of the effect of sarcopenia on dependency in activities of daily living. J. Cachexia Sarcopenia Muscle 2019, 10, 1009-1015. [CrossRef]

15. Yeung, S.S.Y.; Reijnierse, E.M.; Pham, V.K.; Trappenburg, M.C.; Lim, W.K.; Meskers, C.G.M.; Maier, A.B. Sarcopenia and its association with falls and fractures in older adults: A systematic review and meta-analysis. J. Cachexia Sarcopenia Muscle 2019, 10, 485-500. [CrossRef] 
16. Uemura, K.; Doi, T.; Lee, S.; Shimada, H. Sarcopenia and Low Serum Albumin Level Synergistically Increase the Risk of Incident Disability in Older Adults. J. Am. Med. Dir. Assoc. 2019, 20, 90-93. [CrossRef]

17. Deniz, O.; Coteli, S.; Karatoprak, N.B.; Pence, M.C.; Varan, H.D.; Kizilarslanoglu, M.C.; Oktar, S.O.; Goker, B. Diaphragmatic muscle thickness in older people with and without sarcopenia. Aging Clin. Exp. Res. 2020. [CrossRef]

18. Locquet, M.; Beaudart, C.; Hajaoui, M.; Petermans, J.; Reginster, J.Y.; Bruyère, O. Three-Year Adverse Health Consequences of Sarcopenia in Community-Dwelling Older Adults According to 5 Diagnosis Definitions. J. Am. Med. Dir. Assoc. 2019, 20, 43-46.e2. [CrossRef]

19. Buckinx, F.; Landi, F.; Cesari, M.; Fielding, R.A.; Visser, M.; Engelke, K.; Maggi, S.; Dennison, E.; Al-Daghri, N.M.; Allepaerts, S.; et al. Pitfalls in the measurement of muscle mass: A need for a reference standard. J. Cachexia Sarcopenia Muscle 2018, 9, 269-278. [CrossRef]

20. Scafoglieri, A.; Clarys, J.P. Dual energy X-ray absorptiometry: Gold standard for muscle mass? J. Cachexia Sarcopenia Muscle 2018, 9, 786-787. [CrossRef]

21. Evans, W.J.; Hellerstein, M.; Orwoll, E.; Cummings, S.; Cawthon, P.M. $\mathrm{D}_{3}$-Creatine dilution and the importance of accuracy in the assessment of skeletal muscle mass. J. Cachexia Sarcopenia Muscle 2019, 10, 14-21. [CrossRef] [PubMed]

22. Shankaran, M.; Czerwieniec, G.; Fessler, C.; Wong, P.A.; Killion, S.; Turner, S.M.; Hellerstein, M.K.; Evans, W.J. Dilution of oral $\mathrm{D}_{3}$-Creatine to measure creatine pool size and estimate skeletal muscle mass: Development of a correction algorithm. J. Cachexia Sarcopenia Muscle 2018, 9, 540-546. [CrossRef] [PubMed]

23. Sánchez-Sánchez, J.L.; Mañas, A.; García-García, F.J.; Ara, I.; Carnicero, J.A.; Walter, S.; Rodríguez-Mañas, L. Sedentary behaviour, physical activity, and sarcopenia among older adults in the TSHA: Isotemporal substitution model. J. Cachexia Sarcopenia Muscle 2019, 10, 188-198. [CrossRef] [PubMed]

24. Neves, T.; Fett, C.A.; Ferriolli, E.; Souza, M.G.C.; dos Reis Filho, A.D.; Lopes, M.B.M.; Martins, N.M.C.; Fett, W.C.R. Correlation between muscle mass, nutritional status and physical performance of elderly people. Osteoporos Sarcopenia 2018, 4, 145-149. [CrossRef] [PubMed]

25. Scherbakov, N.; Doehner, W. Do we need a reference standard for the muscle mass measurements? ESC Heart Fail 2018, 5, 741-744. [CrossRef]

26. Petermann-Rocha, F.; Ho, F.K.; Welsh, P.; Mackay, D.; Brown, R.; Gill, J.M.R.; Sattar, N.; Gray, S.R.; Pell, J.P.; Celis-Morales, C.A. Physical capability markers used to define sarcopenia and their association with cardiovascular and respiratory outcomes and all-cause mortality: A prospective study from UK Biobank. Maturitas 2020, 138, 69-75. [CrossRef] [PubMed]

27. Tabara, Y.; Ikezoe, T.; Setoh, K.; Sugimoto, K.; Kawaguchi, T.; Kosugi, S.; Nakayama, T.; Ichihashi, N.; Tsuboyama, T.; Matsuda, F.; et al. Comparison of diagnostic significance of the initial versus revised diagnostic algorithm for sarcopenia from the Asian Working Group for Sarcopenia. Arch. Gerontol. Geriatr. 2020, 89, 104071. [CrossRef] [PubMed]

28. Chen, L.K.; Woo, J.; Assantachai, P.; Auyeung, T.W.; Chou, M.Y.; Iijima, K.; Jang, H.C.; Kang, L.; Kim, M.; Kim, S.; et al. Asian Working Group for Sarcopenia: 2019 Consensus Update on Sarcopenia Diagnosis and Treatment. J. Am. Med. Dir. Assoc. 2020, 21, 300-307.e2. [CrossRef] [PubMed]

29. Curcio, F.; Testa, G.; Liguori, I.; Papillo, M.; Flocco, V.; Panicara, V.; Galizia, G.; Della-Morte, D.; Gargiulo, G.; Cacciatore, F.; et al. Sarcopenia and Heart Failure. Nutrients 2020, 12, 211. [CrossRef] [PubMed]

30. Lee, W.J.; Peng, L.N.; Loh, C.H.; Chen, L.K. Sex-different associations between serum homocysteine, high-sensitivity C-reactive protein and sarcopenia: Results from I-Lan Longitudinal Aging Study. Exp. Gerontol. 2020, 132, 110832. [CrossRef]

31. Wen, C.P.; Wai, J.P.; Tsai, M.K.; Yang, Y.C.; Cheng, T.Y.; Lee, M.C.; Chan, H.T.; Tsao, C.K.; Tsai, S.P.; Wu, X. Minimum amount of physical activity for reduced mortality and extended life expectancy: A prospective cohort study. Lancet 2011, 378, 1244-1253. [CrossRef]

32. Haraldstad, K.; Rohde, G.; Stea, T.H.; Lohne-Seiler, H.; Hetlelid, K.; Paulsen, G.; Berntsen, S. Changes in health-related quality of life in elderly men after 12 weeks of strength training. Eur. Rev. Aging Phys. Act. 2017, 14, 8. [CrossRef] [PubMed]

33. Kim, H.K.; Suzuki, T.; Saito, K.; Yoshida, H.M.; Kobayashi, H.; Kato, H.; Katayama, M. Effects of exercise and amino acid supplementation on body composition and physical function in community-dwelling elderly Japanese sarcopenic women: A randomized controlled trial. J. Am. Geriatr. Soc. 2012, 60, 16-23. [CrossRef] [PubMed] 
34. Beasley, J.M.; Shikany, J.M.; Thomson, C.A. The role of dietary protein intake in the prevention of sarcopenia of aging. Nutr. Clin. Pract. 2013, 28, 684-690. [CrossRef] [PubMed]

35. Karlsson, M.; Becker, W.; Michaëlsson, K.; Cederholm, T.; Sjögren, P. Associations between dietary patterns at age 71 and the prevalence of sarcopenia 16 years later. Clin. Nutr. 2020, 39, 1077-1084. [CrossRef]

36. Rondanelli, M.; Rigon, C.; Perna, S.; Gasparri, C.; Iannello, G.; Akber, R.; Alalwan, T.A.; Freije, A.M. Novel Insights on Intake of Fish and Prevention of Sarcopenia: All Reasons for an Adequate Consumption. Nutrients 2020, 12, 307. [CrossRef]

37. Tao, J.; Ke, Y.Y.; Zhang, Z.; Zhang, Y.; Wang, Y.Y.; Ren, C.X.; Xu, J.; Zhu, Y.X.; Zhang, X.L.; Zhang, X.Y. Comparison of the value of malnutrition and sarcopenia for predicting mortality in hospitalized old adults over 80 years. Exp. Gerontol. 2020, 138, 111007. [CrossRef]

38. Lu, Y.; Karagounis, L.G.; Ng, T.P.; Carre, C.; Narang, V.; Wong, G.; Tan, C.T.Y.; Zin Nyunt, M.S.; Gao, Q.; Abel, B.; et al. Systemic and Metabolic Signature of Sarcopenia in Community-Dwelling Older Adults. J. Gerontol. A Biol. Sci. Med. Sci. 2020, 75, 309-317. [CrossRef]

39. Oost, L.J.; Kustermann, M.; Armani, A.; Blaauw, B.; Romanello, V. Fibroblast growth factor 21 controls mitophagy and muscle mass. J. Cachexia Sarcopenia Muscle 2019, 10, 630-642. [CrossRef]

40. Gill, J.F.; Santos, G.; Schnyder, S.; Handschin, C. PGC-1 $\alpha$ affects aging-related changes in muscle and motor function by modulating specific exercise-mediated changes in old mice. Aging Cell 2018, 17, e12697. [CrossRef]

41. Migliavacca, E.; Tay, S.; Patel, H.P.; Sonntag, T.; Civiletto, G.; McFarlane, C.; Forrester, T.; Barton, S.J.; Leow, M.K.; Antoun, E.; et al. Mitochondrial oxidative capacity and NAD. Nat. Commun. 2019, 10, 5808. [CrossRef] [PubMed]

42. Zhang, Q.; Duplany, A.; Moncollin, V.; Mouradian, S.; Goillot, E.; Mazelin, L.; Gauthier, K.; Streichenberger, N.; Angleraux, C.; Chen, J.; et al. Lack of muscle mTOR kinase activity causes early onset myopathy and compromises whole-body homeostasis. J. Cachexia Sarcopenia Muscle 2019, 10, 35-53. [CrossRef] [PubMed]

43. Joseph, G.A.; Wang, S.X.; Jacobs, C.E.; Zhou, W.; Kimble, G.C.; Tse, H.W.; Eash, J.K.; Shavlakadze, T.; Glass, D.J. Partial Inhibition of mTORC1 in Aged Rats Counteracts the Decline in Muscle Mass and Reverses Molecular Signaling Associated with Sarcopenia. Mol. Cell Biol. 2019, 39, e00141-19. [CrossRef] [PubMed]

44. Crespo-Leiro, M.G.; Metra, M.; Lund, L.H.; Milicic, D.; Costanzo, M.R.; Filippatos, G.; Gustafsson, F.; Tsui, S.; Barge-Caballero, E.; De Jonge, N.; et al. European Society of Cardiology Heart Failure Long-Term Registry (ESC-HF-LT): 1-year follow-up outcomes and differences across regions. Eur. J. Heart Fail 2016, 18, 613-625. [CrossRef] [PubMed]

45. Hao, G.; Wang, X.; Chen, Z.; Zhang, L.; Zhang, Y.; Wei, B.; Zheng, C.; Kang, Y.; Jiang, L.; Zhu, Z.; et al. Prevalence of heart failure and left ventricular dysfunction in China: The China Hypertension Survey, 2012-2015. Eur. J. Heart Fail 2019, 21, 1329-1337. [CrossRef] [PubMed]

46. Liao, L.; Allen, L.A.; Whellan, D.J. Economic burden of heart failure in the elderly. Pharmacoeconomics 2008, 26, 447-462. [CrossRef]

47. Aziz, W.; Claridge, S.; Ntalas, I.; Gould, J.; de Vecchi, A.; Razeghi, O.; Toth, D.; Mountney, P.; Preston, R.; Rinaldi, C.A.; et al. Emerging role of cardiac computed tomography in heart failure. ESC Heart Fail 2019, 6, 909-920. [CrossRef]

48. Lavall, D.; Hagendorff, A.; Schirmer, S.H.; Böhm, M.; Borger, M.A.; Laufs, U. Mitral valve interventions in heart failure. ESC Heart Fail 2018, 5, 552-561. [CrossRef]

49. Mullens, W.; Damman, K. Response to letters on "The use of diuretics in heart failure with congestion-A position statement from the Heart Failure Association of the European Society of Cardiology". Eur. J. Heart Fail. 2019, 21, 949-950. [CrossRef]

50. Kaye, D.M.; Petrie, M.C.; McKenzie, S.; Hasenfuß, G.; Malek, F.; Post, M.; Doughty, R.N.; Trochu, J.N.; Gustafsson, F.; Lang, I.; et al. Impact of an interatrial shunt device on survival and heart failure hospitalization in patients with preserved ejection fraction. ESC Heart Fail. 2019, 6, 62-69. [CrossRef]

51. Crespo-Leiro, M.G.; Metra, M.; Lund, L.H.; Milicic, D.; Costanzo, M.R.; Filippatos, G.; Gustafsson, F.; Tsui, S.; Barge-Caballero, E.; De Jonge, N.; et al. Advanced heart failure: A position statement of the Heart Failure Association of the European Society of Cardiology. Eur. J. Heart Fail. 2018, 20, 1505-1535. [CrossRef] [PubMed] 
52. Vitale, C.; Jankowska, E.; Hill, L.; Piepoli, M.; Doehner, W.; Anker, S.D.; Lainscak, M.; Jaarsma, T.; Ponikowski, P.; Rosano, G.M.C.; et al. Heart Failure Association/European Society of Cardiology position paper on frailty in patients with heart failure. Eur. J. Heart Fail. 2019, 21, 1299-1305. [CrossRef] [PubMed]

53. Benjamin, E.J.; Blaha, M.J.; Chiuve, S.E.; Cushman, M.; Das, S.R.; Deo, R.; de Ferranti, S.D.; Floyd, J.; Fornage, M. American Heart Association Statistics Committee and Stroke Statistics Subcommittee; et al Heart Disease and Stroke Statistics-2017 Update: A Report from the American Heart Association. Circulation 2017, 135, e146-e603. [CrossRef] [PubMed]

54. Iorio, A.; Senni, M.; Barbati, G.; Greene, S.J.; Poli, S.; Zambon, E.; Di Nora, C.; Cioffi, G.; Tarantini, L.; Gavazzi, A.; et al. Prevalence and prognostic impact of non-cardiac co-morbidities in heart failure outpatients with preserved and reduced ejection fraction: A community-based study. Eur. J. Heart Fail. 2018, 20, 1257-1266. [CrossRef]

55. Tomasoni, D.; Adamo, M.; Lombardi, C.M.; Metra, M. Highlights in heart failure. ESC Heart Fail. 2019, 6, 1105-1127. [CrossRef]

56. Löfström, U.; Hage, C.; Savarese, G.; Donal, E.; Daubert, J.C.; Lund, L.H.; Linde, C. Prognostic impact of Framingham heart failure criteria in heart failure with preserved ejection fraction. ESC Heart Fail. 2019, 6, 830-839. [CrossRef]

57. Suzuki, T.; Palus, S.; Springer, J. Skeletal muscle wasting in chronic heart failure. ESC Heart Fail. 2018, 5, 1099-1107. [CrossRef]

58. Tsuji, M.; Amiya, E.; Hatano, M.; Nitta, D.; Maki, H.; Bujo, C.; Saito, A.; Hosoya, Y.; Minatsuki, S.; Hara, T.; et al. Abdominal skeletal muscle mass as a predictor of mortality in Japanese patients undergoing left ventricular assist device implantation. ESC Heart Fail. 2019, 6, 526-535. [CrossRef]

59. Martone, A.M.; Bianchi, L.; Abete, P.; Bellelli, G.; Bo, M.; Cherubini, A.; Corica, F.; Di Bari, M.; Maggio, M.; Manca, G.M.; et al. The incidence of sarcopenia among hospitalized older patients: Results from the Glisten study. J. Cachexia Sarcopenia Muscle 2017, 8, 907-914. [CrossRef]

60. Platz, E.; Jhund, P.S.; Claggett, B.L.; Pfeffer, M.A.; Swedberg, K.; Granger, C.B.; Yusuf, S.; Solomon, S.D.; McMurray, J.J. Prevalence and prognostic importance of precipitating factors leading to heart failure hospitalization: Recurrent hospitalizations and mortality. Eur. J. Heart Fail. 2018, 20, 295-303. [CrossRef]

61. von Haehling, S. Muscle wasting and sarcopenia in heart failure: A brief overview of the current literature. ESC Heart Fail. 2018, 5, 1074-1082. [CrossRef]

62. Emami, A.; Saitoh, M.; Valentova, M.; Sandek, A.; Evertz, R.; Ebner, N.; Loncar, G.; Springer, J.; Doehner, W.; Lainscak, M.; et al. Comparison of sarcopenia and cachexia in men with chronic heart failure: Results from the Studies Investigating Co-morbidities Aggravating Heart Failure (SICA-HF). Eur. J. Heart Fail. 2018, 20, 1580-1587. [CrossRef] [PubMed]

63. Streng, K.W.; Nauta, J.F.; Hillege, H.L.; Anker, S.D.; Cleland, J.G.; Dickstein, K.; Filippatos, G.; Lang, C.C.; Metra, M.; Ng, L.L.; et al. Non-cardiac comorbidities in heart failure with reduced, mid-range and preserved ejection fraction. Int. J. Cardiol. 2018, 271, 132-139. [CrossRef] [PubMed]

64. Bekfani, T.; Pellicori, P.; Morris, D.A.; Ebner, N.; Valentova, M.; Steinbeck, L.; Wachter, R.; Elsner, S.; Sliziuk, V.; Schefold, J.C.; et al. Sarcopenia in patients with heart failure with preserved ejection fraction: Impact on muscle strength, exercise capacity and quality of life. Int. J. Cardiol. 2016, 222, 41-46. [CrossRef]

65. Tucker, W.J.; Haykowsky, M.J.; Seo, Y.; Stehling, E.; Forman, D.E. Impaired Exercise Tolerance in Heart Failure: Role of Skeletal Muscle Morphology and Function. Curr. Heart Fail Rep. 2018, 15, 323-331. [CrossRef] [PubMed]

66. Yin, J.; Lu, X.; Qian, Z.; Xu, W.; Zhou, X. New insights into the pathogenesis and treatment of sarcopenia in chronic heart failure. Theranostics 2019, 9, 4019-4029. [CrossRef]

67. Jeng, C.; Zhao, L.J.; Wu, K.; Zhou, Y.; Chen, T.; Deng, H.W. Race and socioeconomic effect on sarcopenia and sarcopenic obesity in the Louisiana Osteoporosis Study (LOS). JCSM Clin. Rep. 2018, 3, e00027. [CrossRef]

68. Tyrovolas, S.; Koyanagi, A.; Olaya, B.; Ayuso-Mateos, J.L.; Miret, M.; Chatterji, S.; Tobiasz-Adamczyk, B.; Koskinen, S.; Leonardi, M.; Haro, J.M. Factors associated with skeletal muscle mass, sarcopenia, and sarcopenic obesity in older adults: A multi-continent study. J. Cachexia Sarcopenia Muscle 2016, 7, 312-321. [CrossRef]

69. Carbone, S.; Billingsley, H.E.; Rodriguez-Miguelez, P.; Kirkman, D.L.; Garten, R.; Franco, R.L.; Lee, D.C.; Lavie, C.J. Lean Mass Abnormalities in Heart Failure: The Role of Sarcopenia, Sarcopenic Obesity, and Cachexia. Curr. Probl. Cardiol. 2019, 100417. [CrossRef] 
70. Markousis-Mavrogenis, G.; Tromp, J.; Ouwerkerk, W.; Devalaraja, M.; Anker, S.D.; Cleland, J.G.; Dickstein, K.; Filippatos, G.S.; van der Harst, P.; Lang, C.C.; et al. The clinical significance of interleukin-6 in heart failure: Results from the BIOSTAT-CHF study. Eur. J. Heart Fail. 2019, 21, 965-973. [CrossRef]

71. Berry, C.; Clark, A.L. Catabolism in chronic heart failure. Eur. Heart J. 2000, 21, 521-532. [CrossRef]

72. von Haehling, S.; Ebner, N.; Dos Santos, M.R.; Springer, J.; Anker, S.D. Muscle wasting and cachexia in heart failure: Mechanisms and therapies. Nat. Rev. Cardiol. 2017, 14, 323-341. [CrossRef]

73. Bossone, E.; Arcopinto, M.; Iacoviello, M.; Triggiani, V.; Cacciatore, F.; Maiello, C.; Limongelli, G.; Masarone, D.; Perticone, F.; Sciacqua, A.; et al. Multiple hormonal and metabolic deficiency syndrome in chronic heart failure: Rationale, design, and demographic characteristics of the T.O.S.CA. Registry. Int. Emerg. Med. 2018, 13, 661-671. [CrossRef]

74. D'Assante, R.; Napoli, R.; Salzano, A.; Pozza, C.; Marra, A.M.; Arcopinto, M.; Perruolo, G.; Milano, S.; Formisano, P.; Saldamarco, L.; et al. Human heart shifts from IGF-1 production to utilization with chronic heart failure. Endocrine 2019, 65, 714-716. [CrossRef]

75. Boxer, R.S.; Dauser, D.A.; Walsh, S.J.; Hager, W.D.; Kenny, A.M. The association between vitamin D and inflammation with the 6-minute walk and frailty in patients with heart failure. J. Am. Geriatr. Soc. 2008, 56, 454-461. [CrossRef]

76. Jankowska, E.A.; Biel, B.; Majda, J.; Szklarska, A.; Lopuszanska, M.; Medras, M.; Anker, S.D.; Banasiak, W.; Poole-Wilson, P.A.; Ponikowski, P. Anabolic deficiency in men with chronic heart failure: Prevalence and detrimental impact on survival. Circulation 2006, 114, 1829-1837. [CrossRef]

77. Marra, A.M.; Bobbio, E.; D’Assante, R.; Salzano, A.; Arcopinto, M.; Bossone, E.; Cittadini, A. Growth Hormone as Biomarker in Heart Failure. Heart Fail. Clin. 2018, 14, 65-74. [CrossRef]

78. Bian, A.; Ma, Y.; Zhou, X.; Guo, Y.; Wang, W.; Zhang, Y.; Wang, X. Association between sarcopenia and levels of growth hormone and insulin-like growth factor-1 in the elderly. BMC Musculoskelet Disord. 2020, $21,214$. [CrossRef]

79. Morley, J.E. Pharmacologic Options for the Treatment of Sarcopenia. Calcif. Tissue Int. 2016, 98, 319-333. [CrossRef]

80. Giovannini, S.; Marzetti, E.; Borst, S.E.; Leeuwenburgh, C. Modulation of GH/IGF-1 axis: Potential strategies to counteract sarcopenia in older adults. Mech. Ageing Dev. 2008, 129, 593-601. [CrossRef]

81. Islam, T.; Peiris, P.; Copeland, R.J.; El Zoghby, M.; Peiris, A.N. Vitamin D: Lessons from the veterans population. J. Am. Med. Dir. Assoc. 2011, 12, 257-262. [CrossRef]

82. Muir, S.W.; Montero-Odasso, M. Effect of vitamin D supplementation on muscle strength, gait and balance in older adults: A systematic review and meta-analysis. J. Am. Geriatr. Soc. 2011, 59, 2291-2300. [CrossRef]

83. Porto, C.M.; Silva, V.L.; da Luz, J.S.B.; Filho, B.M.; da Silveira, V.M. Association between vitamin D deficiency and heart failure risk in the elderly. ESC Heart Fail. 2018, 5, 63-74. [CrossRef]

84. de Boer, R.A.; Meems, L.M.G.; van Veldhuisen, D.J. Vitamin D supplementation in heart failure: Case closed? Eur. Heart J. 2017, 38, 2287-2289. [CrossRef]

85. Zittermann, A.; Ernst, J.B.; Prokop, S.; Fuchs, U.; Gruszka, A.; Dreier, J.; Kuhn, J.; Knabbe, C.; Berthold, H.K.; Gouni-Berthold, I.; et al. Vitamin D supplementation of 4000 IU daily and cardiac function in patients with advanced heart failure: The EVITA trial. Int. J. Cardiol. 2019, 280, 117-123. [CrossRef]

86. Yoshihisa, A.; Suzuki, S.; Sato, Y.; Kanno, Y.; Abe, S.; Miyata, M.; Sato, T.; Oikawa, M.; Kobayashi, A.; Yamaki, T.; et al. Relation of Testosterone Levels to Mortality in Men with Heart Failure. Am. J. Cardiol. 2018, 121, 1321-1327. [CrossRef]

87. Pugh, P.J.; Jones, R.D.; West, J.N.; Jones, T.H.; Channer, K.S. Testosterone treatment for men with chronic heart failure. Heart 2004, 90, 446-447. [CrossRef]

88. Caminiti, G.; Volterrani, M.; Iellamo, F.; Marazzi, G.; Massaro, R.; Miceli, M.; Mammi, C.; Piepoli, M.; Fini, M.; Rosano, G.M. Effect of long-acting testosterone treatment on functional exercise capacity, skeletal muscle performance, insulin resistance, and baroreflex sensitivity in elderly patients with chronic heart failure a double-blind, placebo-controlled, randomized study. J. Am. Coll. Cardiol. 2009, 54, 919-927. [CrossRef]

89. Gagliano-Jucá, T.; Basaria, S. Testosterone replacement therapy and cardiovascular risk. Nat. Rev. Cardiol. 2019, 16, 555-574. [CrossRef]

90. Borst, S.E.; Shuster, J.J.; Zou, B.; Ye, F.; Jia, H.; Wokhlu, A.; Yarrow, J.F. Cardiovascular risks and elevation of serum DHT vary by route of testosterone administration: A systematic review and meta-analysis. BMC Med. 2014, 12, 211. [CrossRef] 
91. Pu, C.T.; Johnson, M.T.; Forman, D.E.; Hausdorff, J.M.; Roubenoff, R.; Foldvari, M.; Fielding, R.A.; Singh, M.A. Randomized trial of progressive resistance training to counteract the myopathy of chronic heart failure. J. Appl. Physiol. 2001, 90, 2341-2350. [CrossRef]

92. Bacurau, A.V.; Jannig, P.R.; de Moraes, W.M.; Cunha, T.F.; Medeiros, A.; Barberi, L.; Coelho, M.A.; Bacurau, R.F.; Ugrinowitsch, C.; Musarò, A.; et al. Akt/mTOR pathway contributes to skeletal muscle anti-atrophic effect of aerobic exercise training in heart failure mice. Int. J. Cardiol. 2016, 214, 137-147. [CrossRef]

93. Pearson, M.J.; Mungovan, S.F.; Smart, N.A. Effect of aerobic and resistance training on inflammatory markers in heart failure patients: Systematic review and meta-analysis. Heart Fail. Rev. 2018, 23, 209-223. [CrossRef]

94. Saitoh, M.; Ebner, N.; von Haehling, S.; Anker, S.D.; Springer, J. Therapeutic considerations of sarcopenia in heart failure patients. Expert Rev. Cardiovasc. Ther. 2018, 16, 133-142. [CrossRef]

95. Ventura, H.O.; Carbone, S.; Lavie, C.J. Muscling up to improve heart failure prognosis. Eur. J. Heart Fail. 2018, 20, 1588-1590. [CrossRef]

96. Piepoli, M.F.; Conraads, V.; Corrà, U.; Dickstein, K.; Francis, D.P.; Jaarsma, T.; McMurray, J.; Pieske, B.; Piotrowicz, E.M.; Schmid, J.P.; et al. Exercise training in heart failure: From theory to practice. A consensus document of the Heart Failure Association and the European Association for Cardiovascular Prevention and Rehabilitation. Eur. J. Heart Fail. 2011, 13, 347-357. [CrossRef]

97. Aquilani, R.; Opasich, C.; Gualco, A.; Verri, M.; Testa, A.; Pasini, E.; Viglio, S.; Iadarola, P.; Pastoris, O.; Dossena, M.; et al. Adequate energy-protein intake is not enough to improve nutritional and metabolic status in muscle-depleted patients with chronic heart failure. Eur. J. Heart Fail. 2008, 10, 1127-1135. [CrossRef]

98. Sumukadas, D.; Witham, M.D.; Struthers, A.D.; McMurdo, M.E. Ace inhibitors as a therapy for sarcopenia-Evidence and possible mechanisms. J. Nutr. Health Aging 2008, 12, 480-485. [CrossRef]

99. Vescovo, G.; Dalla Libera, L.; Serafini, F.; Leprotti, C.; Facchin, L.; Volterrani, M.; Ceconi, C.; Ambrosio, G.B. Improved exercise tolerance after losartan and enalapril in heart failure: Correlation with changes in skeletal muscle myosin heavy chain composition. Circulation 1998, 98, 1742-1749. [CrossRef]

100. Anker, S.D.; Negassa, A.; Coats, A.J.; Afzal, R.; Poole-Wilson, P.A.; Cohn, J.N.; Yusuf, S. Prognostic importance of weight loss in chronic heart failure and the effect of treatment with angiotensin-converting-enzyme inhibitors: An observational study. Lancet 2003, 361, 1077-1083. [CrossRef]

101. Spira, D.; Walston, J.; Buchmann, N.; Nikolov, J.; Demuth, I.; Steinhagen-Thiessen, E.; Eckardt, R.; Norman, K. Angiotensin-Converting Enzyme Inhibitors and Parameters of Sarcopenia: Relation to Muscle Mass, Strength and Function: Data from the Berlin Aging Study-II (BASE-II). Drugs Aging 2016, 33, 829-837. [CrossRef]

102. Sumukadas, D.; Witham, M.D.; Struthers, A.D.; McMurdo, M.E. Effect of perindopril on physical function in elderly people with functional impairment: A randomized controlled trial. CMAJ 2007, 177, 867-874. [CrossRef]

103. Song, Y.H.; Li, Y.; Du, J.; Mitch, W.E.; Rosenthal, N.; Delafontaine, P. Muscle-specific expression of IGF-1 blocks angiotensin II-induced skeletal muscle wasting. J. Clin. Investig. 2005, 115, 451-458. [CrossRef]

104. Echeverría-Rodríguez, O.; Del Valle-Mondragón, L.; Hong, E. Angiotensin 1-7 improves insulin sensitivity by increasing skeletal muscle glucose uptake in vivo. Peptides 2014, 51, 26-30. [CrossRef]

105. Burton, L.A.; McMurdo, M.E.; Struthers, A.D. Mineralocorticoid antagonism: A novel way to treat sarcopenia and physical impairment in older people? Clin. Endocrinol. 2011, 75, 725-729. [CrossRef]

106. Hernández, N.; Torres, S.H.; Finol, H.J.; Sosa, A.; Cierco, M. Capillary and muscle fiber type changes in DOCA-salt hypertensive rats. Anat. Rec. 1996, 246, 208-216. [CrossRef]

107. Edelmann, F.; Wachter, R.; Schmidt, A.G.; Kraigher-Krainer, E.; Colantonio, C.; Kamke, W.; Duvinage, A.; Stahrenberg, R.; Durstewitz, K.; Löffler, M.; et al. Effect of spironolactone on diastolic function and exercise capacity in patients with heart failure with preserved ejection fraction: The Aldo-DHF randomized controlled trial. JAMA 2013, 309, 781-791. [CrossRef]

108. Burton, L.A.; Sumukadas, D.; Witham, M.D.; Struthers, A.D.; McMurdo, M.E. Effect of spironolactone on physical performance in older people with self-reported physical disability. Am. J. Med. 2013, 126, 590-597. [CrossRef]

109. Clark, A.L.; Coats, A.J.S.; Krum, H.; Katus, H.A.; Mohacsi, P.; Salekin, D.; Schultz, M.K.; Packer, M.; Anker, S.D. Effect of beta-adrenergic blockade with carvedilol on cachexia in severe chronic heart failure: Results from the COPERNICUS trial. J. Cachexia Sarcopenia Muscle 2017, 8, 549-556. [CrossRef] 
110. Stewart Coats, A.J.; Ho, G.F.; Prabhash, K.; von Haehling, S.; Tilson, J.; Brown, R.; Beadle, J.; Anker, S.D. Espindolol for the treatment and prevention of cachexia in patients with stage III/IV non-small cell lung cancer or colorectal cancer: A randomized, double-blind, placebo-controlled, international multicentre phase II study (the ACT-ONE trial). J. Cachexia Sarcopenia Muscle 2016, 7, 355-365. [CrossRef]

111. Pötsch, M.S.; Ishida, J.; Palus, S.; Tschirner, A.; von Haehling, S.; Doehner, W.; Anker, S.D.; Springer, J. MT-102 prevents tissue wasting and improves survival in a rat model of severe cancer cachexia. J. Cachexia Sarcopenia Muscle 2020, 11, 594-605. [CrossRef]

112. Pötsch, M.S.; Tschirner, A.; Palus, S.; von Haehling, S.; Doehner, W.; Beadle, J.; Coats, A.J.; Anker, S.D.; Springer, J. The anabolic catabolic transforming agent (ACTA) espindolol increases muscle mass and decreases fat mass in old rats. J. Cachexia Sarcopenia Muscle 2014, 5, 149-158. [CrossRef]

113. Lena, A.; Ebner, N.; Coats, A.J.S.; Anker, M.S. Cardiac cachexia: The mandate to increase clinician awareness. Curr. Opin. Support Palliat Care 2019, 13, 298-304. [CrossRef]

114. Barazzoni, R.; Gortan Cappellari, G.; Palus, S.; Vinci, P.; Ruozi, G.; Zanetti, M.; Semolic, A.; Ebner, N.; von Haehling, S.; Sinagra, G.; et al. Acylated ghrelin treatment normalizes skeletal muscle mitochondrial oxidative capacity and AKT phosphorylation in rat chronic heart failure. J. Cachexia Sarcopenia Muscle 2017, 8, 991-998. [CrossRef]

115. Palus, S.; Schur, R.; Akashi, Y.J.; Bockmeyer, B.; Datta, R.; Halem, H.; Dong, J.; Culler, M.D.; Adams, V.; Anker, S.D.; et al. Ghrelin and its analogues, BIM-28131 and BIM-28125, improve body weight and regulate the expression of MuRF-1 and MAFbx in a rat heart failure model. PLoS ONE 2011, 6, e26865. [CrossRef]

116. Nagaya, N.; Moriya, J.; Yasumura, Y.; Uematsu, M.; Ono, F.; Shimizu, W.; Ueno, K.; Kitakaze, M.; Miyatake, K.; Kangawa, K. Effects of ghrelin administration on left ventricular function, exercise capacity, and muscle wasting in patients with chronic heart failure. Circulation 2004, 110, 3674-3679. [CrossRef]

117. Blum, R.A.; Mair, S.; Duus, E.M. Appetite and food intake results from phase I studies of anamorelin. J. Cachexia Sarcopenia Muscle 2019, 10, 1027-1035. [CrossRef]

118. Currow, D.C.; Maddocks, M.; Cella, D.; Muscaritoli, M. Efficacy of Anamorelin, a Novel Non-Peptide Ghrelin Analogue, in Patients with Advanced Non-Small Cell Lung Cancer (NSCLC) and Cachexia-Review and Expert Opinion. Int. J. Mol. Sci. 2018, 19, 3471. [CrossRef]

119. Bowen, T.S.; Adams, V.; Werner, S.; Fischer, T.; Vinke, P.; Brogger, M.N.; Mangner, N.; Linke, A.; Sehr, P.; Lewis, J.; et al. Small-molecule inhibition of MuRF1 attenuates skeletal muscle atrophy and dysfunction in cardiac cachexia. J. Cachexia Sarcopenia Muscle 2017, 8, 939-953. [CrossRef]

120. Welle, S.; Cardillo, A.; Zanche, M.; Tawil, R. Skeletal muscle gene expression after myostatin knockout in mature mice. Physiol. Genom. 2009, 38, 342-350. [CrossRef]

121. Elkina, Y.; von Haehling, S.; Anker, S.D.; Springer, J. The role of myostatin in muscle wasting: An overview. J. Cachexia Sarcopenia Muscle 2011, 2, 143-151. [CrossRef]

122. Ishida, J.; Konishi, M.; Saitoh, M.; Anker, M.; Anker, S.D.; Springer, J. Myostatin signaling is up-regulated in female patients with advanced heart failure. Int. J. Cardiol. 2017, 238, 37-42. [CrossRef]

123. Heineke, J.; Auger-Messier, M.; Xu, J.; Sargent, M.; York, A.; Welle, S.; Molkentin, J.D. Genetic deletion of myostatin from the heart prevents skeletal muscle atrophy in heart failure. Circulation 2010, 121, 419-425. [CrossRef]

124. Ding, H.; Zhang, G.; Sin, K.W.; Liu, Z.; Lin, R.K.; Li, M.; Li, Y.P. Activin A induces skeletal muscle catabolism via p38beta mitogen-activated protein kinase. J. Cachexia Sarcopenia Muscle 2017, 8, 202-212. [CrossRef]

125. Loumaye, A.; de Barsy, M.; Nachit, M.; Lause, P.; van Maanen, A.; Trefois, P.; Gruson, D.; Thissen, J.P. Circulating Activin A predicts survival in cancer patients. J. Cachexia Sarcopenia Muscle 2017, 8, 768-777. [CrossRef]

126. Hulmi, J.J.; Nissinen, T.A.; Räsänen, M.; Degerman, J.; Lautaoja, J.H.; Hemanthakumar, K.A.; Backman, J.T.; Ritvos, O.; Silvennoinen, M.; Kivelä, R. Prevention of chemotherapy-induced cachexia by ACVR2B ligand blocking has different effects on heart and skeletal muscle. J. Cachexia Sarcopenia Muscle 2018, 9, 417-432. [CrossRef]

127. Solomon, Z.J.; Mirabal, J.R.; Mazur, D.J.; Kohn, T.P.; Lipshultz, L.I.; Pastuszak, A.W. Selective Androgen Receptor Modulators: Current Knowledge and Clinical Applications. Sex Med. Rev. 2019, 7, 84-94. [CrossRef] [PubMed] 
128. Dobs, A.S.; Boccia, R.V.; Croot, C.C.; Gabrail, N.Y.; Dalton, J.T.; Hancock, M.L.; Johnston, M.A.; Steiner, M.S. Effects of enobosarm on muscle wasting and physical function in patients with cancer: A double-blind, randomised controlled phase 2 trial. Lancet Oncol. 2013, 14, 335-345. [CrossRef]

129. Neil, D.; Clark, R.V.; Magee, M.; Billiard, J.; Chan, A.; Xue, Z.; Russell, A. GSK2881078, a SARM, Produces Dose-Dependent Increases in Lean Mass in Healthy Older Men and Women. J. Clin. Endocrinol. Metab. 2018, 103, 3215-3224. [CrossRef]

130. Chisamore, M.J.; Gentile, M.A.; Dillon, G.M.; Baran, M.; Gambone, C.; Riley, S.; Schmidt, A.; Flores, O.; Wilkinson, H.; Alves, S.E. A novel selective androgen receptor modulator (SARM) MK-4541 exerts anti-androgenic activity in the prostate cancer xenograft R-3327G and anabolic activity on skeletal muscle mass \& function in castrated mice. J. Steroid Biochem. Mol. Biol. 2016, 163, 88-97.

131. Kiyuna, L.A.; Albuquerque, R.P.E.; Chen, C.H.; Mochly-Rosen, D.; Ferreira, J.C.B. Targeting mitochondrial dysfunction and oxidative stress in heart failure: Challenges and opportunities. Free Radic. Biol. Med. 2018, 129, 155-168. [CrossRef] [PubMed]

132. Cunha, T.F.; Bacurau, A.V.; Moreira, J.B.; Paixão, N.A.; Campos, J.C.; Ferreira, J.C.; Leal, M.L.; Negrão, C.E.; Moriscot, A.S.; Wisløff, U. Exercise training prevents oxidative stress and ubiquitin-proteasome system overactivity and reverse skeletal muscle atrophy in heart failure. PLoS ONE 2012, 7, e41701. [CrossRef] [PubMed]

133. von Haehling, S. The wasting continuum in heart failure: From sarcopenia to cachexia. Proc. Nutr. Soc. 2015, 74, 367-377. [CrossRef]

134. Niedziela, J.T.; Hudzik, B.; Strojek, K.; Poloński, L.; Gąsior, M.; Rozentryt, P. Weight loss in heart failure is associated with increased mortality only in non-obese patients without diabetes. J. Cachexia Sarcopenia Muscle 2019, 10, 1307-1315. [CrossRef]

135. Christensen, H.M.; Kistorp, C.; Schou, M.; Keller, N.; Zerahn, B.; Frystyk, J.; Schwarz, P.; Faber, J. Prevalence of cachexia in chronic heart failure and characteristics of body composition and metabolic status. Endocrine 2013, 43, 626-634. [CrossRef] [PubMed]

136. Morishita, T.; Uzui, H.; Ishida, K.; Kaseno, K.; Miyazaki, S.; Fukuoka, Y.; Ikeda, H.; Tama, N.; Shiomi, Y.; Yamaguchi, J.; et al. P4730 Associations of cachexia and prognosis in patients with heart failure. Eur. Heart J. 2018, 39, ehy563. [CrossRef]

137. Santarpia, L.; Contaldo, F.; Pasanisi, F. Dietary protein content for an optimal diet: A clinical view. J. Cachexia Sarcopenia Muscle 2017, 8, 345-348. [CrossRef]

138. Refsgaard Holm, M.; Christensen, H.; Rasmussen, J.M.; Johansen, M.L.; Schou, M.; Faber, J.; Kistorp, C. Fibroblast growth factor 21 in patients with cardiac cachexia: A possible role of chronic inflammation. ESC Heart Fail. 2019, 6, 983-991. [CrossRef]

139. Scherbakov, N.; Doehner, W. Cachexia as a common characteristic in multiple chronic disease. J. Cachexia Sarcopenia Muscle 2018, 9, 1189-1191. [CrossRef]

140. Kwan, H.Y.; Maddocks, M.; Nolan, C.M.; Jones, S.E.; Patel, S.; Barker, R.E.; Kon, S.; Polkey, M.I.; Cullinan, P.; Man, W.D. The prognostic significance of weight loss in chronic obstructive pulmonary disease-related cachexia: A prospective cohort study. J. Cachexia Sarcopenia Muscle 2019, 10, 1330-1338. [CrossRef]

141. Ziolkowski, S.L.; Long, J.; Baker, J.F.; Chertow, G.M.; Leonard, M.B. Relative sarcopenia and mortality and the modifying effects of chronic kidney disease and adiposity. J. Cachexia Sarcopenia Muscle 2019, 10, 338-346. [CrossRef] [PubMed]

142. Wu, J.; Dong, J.; Verzola, D.; Hruska, K.; Garibotto, G.; Hu, Z.; Mitch, W.E.; Thomas, S.S. Signal regulatory protein alpha initiates cachexia through muscle to adipose tissue crosstalk. J. Cachexia Sarcopenia Muscle 2019, 10, 1210-1227. [CrossRef] [PubMed]

143. Lena, A.; Coats, A.J.S.; Anker, M.S. Metabolic disorders in heart failure and cancer. ESC Heart Fail. 2018, 5 , 1092-1098. [CrossRef] [PubMed]

144. Valentova, M.; von Haehling, S.; Bauditz, J.; Doehner, W.; Ebner, N.; Bekfani, T.; Elsner, S.; Sliziuk, V.; Scherbakov, N.; Murín, J.; et al. Intestinal congestion and right ventricular dysfunction: A link with appetite loss, inflammation, and cachexia in chronic heart failure. Eur. Heart J. 2016, 37, 1684-1691. [CrossRef] [PubMed]

145. Kitamura, M.; Izawa, K.P.; Yaekura, M.; Mimura, Y.; Nagashima, H.; Oka, K. Differences in nutritional status and activities of daily living and mobility in elderly hospitalized patients with heart failure. ESC Heart Fail. 2019, 6, 344-350. [CrossRef] 
146. Saitoh, M.; Dos Santos, M.R.; Ebner, N.; Emami, A.; Konishi, M.; Ishida, J.; Valentova, M.; Sandek, A.; Doehner, W.; Anker, S.D.; et al. Nutritional status and its effects on muscle wasting in patients with chronic heart failure: Insights from Studies Investigating Co-morbidities Aggravating Heart Failure. Wien Klin Wochenschr 2016, 128, 497-504. [CrossRef]

147. Sente, T.; Van Berendoncks, A.M.; Hoymans, V.Y.; Vrints, C.J. Adiponectin resistance in skeletal muscle: Pathophysiological implications in chronic heart failure. J. Cachexia Sarcopenia Muscle 2016, 7, 261-274. [CrossRef]

148. Araújo, J.P.; Lourenço, P.; Rocha-Gonçalves, F.; Ferreira, A.; Bettencourt, P. Adiponectin is increased in cardiac cachexia irrespective of body mass index. Eur. J. Heart Fail. 2009, 11, 567-572. [CrossRef]

149. McEntegart, M.B.; Awede, B.; Petrie, M.C.; Sattar, N.; Dunn, F.G.; MacFarlane, N.G.; McMurray, J.J. Increase in serum adiponectin concentration in patients with heart failure and cachexia: Relationship with leptin, other cytokines, and B-type natriuretic peptide. Eur. Heart J. 2007, 28, 829-835. [CrossRef]

150. Celik, T.; Yaman, H. Elevated adiponectin levels in patients with chronic heart failure: An independent predictor of mortality or a marker of cardiac cachexia? Int. J. Cardiol. 2010, 144, 319-320. [CrossRef]

151. Szabó, T.; Scherbakov, N.; Sandek, A.; Kung, T.; von Haehling, S.; Lainscak, M.; Jankowska, E.A.; Rudovich, N.; Anker, S.D.; Frystyk, J.; et al. Plasma adiponectin in heart failure with and without cachexia: Catabolic signal linking catabolism, symptomatic status, and prognosis. Nutr. Metab. Cardiovasc. Dis. 2014, 24, 50-56. [CrossRef] [PubMed]

152. Loncar, G.; Bozic, B.; von Haehling, S.; Düngen, H.D.; Prodanovic, N.; Lainscak, M.; Arandjelovic, A.; Dimkovic, S.; Radojicic, Z.; Popovic, V. Association of adiponectin with peripheral muscle status in elderly patients with heart failure. Eur. J. Intern. Med. 2013, 24, 818-823. [CrossRef] [PubMed]

153. Willis, M.S.; Parry, T.L.; Brown, D.I.; Mota, R.I.; Huang, W.; Beak, J.Y.; Sola, M.; Zhou, C.; Hicks, S.T.; Caughey, M.C.; et al. Doxorubicin Exposure Causes Subacute Cardiac Atrophy Dependent on the Striated Muscle-Specific Ubiquitin Ligase MuRF1. Circulation. Heart Fail. 2019, 12, e005234. [CrossRef] [PubMed]

154. Springer, J.; Tschirner, A.; Haghikia, A.; von Haehling, S.; Lal, H.; Grzesiak, A.; Kaschina, E.; Palus, S.; Pötsch, M.; von Websky, K.; et al. Prevention of liver cancer cachexia-induced cardiac wasting and heart failure. Eur. Heart J. 2014, 35, 932-941. [CrossRef]

155. Cruz-Jentoft, A.J.; Baeyens, J.P.; Bauer, J.M.; Boirie, Y.; Cederholm, T.; Landi, F.; Martin, F.C.; Michel, J.P.; Rolland, Y.; European Working Group on Sarcopenia in Older People; et al. Sarcopenia: European consensus on definition and diagnosis: Report of the European Working Group on Sarcopenia in Older People. Age and Ageing 2010, 39, 412-423. [CrossRef]

156. Patel, S.M.; Duchowny, K.A.; Cummings, S.R.; Orwoll, E.S.; Hoffman, A.R.; Enusrud, K.E.; Cauley, J.A.; Evans, W.J.; Cawthon, P.M. Sarcopenia Definition \& Outcomes Consortium Defined Low Grip Strength in Two Cross-Sectional, Population-Based Cohorts. J. Am. Geriatr. Soc. 2020, 68, 1438-1444. 